\title{
Changes in Triticum aestivum and Hordeum vulgare chlorophyll content and fluorescence parameters under impact of various sapropel concentrations
}

\author{
Martynas Klepeckas, \\ Irena Januškaitien $\dot{e}^{\star}$ \\ Vytautas Magnus University, \\ Vileikos St. 8, LT-44404 \\ Kaunas, Lithuania
}

The aim of this study was to investigate the impact of sapropel of Tarosiškis Lake on wheat (Triticum aestivum L.) and barley (Hordeum vulgare L.) photosynthesis parameters (the content of chlorophylls and chlorophyll fluorescence). Plants were sown in one-litre-volume pots by 10 seeds with light loamy soil and grown in growth chambers. Considering sapropel composition, $2.2,3.1$, and $4 \mathrm{t} / \mathrm{ha}$ dry sapropel concentrations were chosen for investigation. Sapropel-affected plants were compared with plants grown in unfertilized soils and soils fertilized with inorganic fertilizer. On day 14 of the experiment, when the plants reached the two-leaves development stage (BBCH 12), chlorophyll fluorescence parameters of the investigated plants were measured. Then the plants were grown for another four weeks and at the stem elongation stage (BBCH 31) chlorophyll fluorescence parameters were measured repeatedly, and the content of chlorophylls and carotenoids were measured as well. By increasing sapropel concentration in soil, the ratio $\mathrm{Fv} / \mathrm{Fm}$ in wheat leaves increased $(r=0.97)$ significantly $(p<0.05)$ at BBCH 12 stage, but at the stem elongation stage the correlation coefficient was insignificant $(r=0.97)(p>0.05)$. Fv/Fm of barley followed the same tendency. By increasing sapropel concentration, the PI index value also increased for wheat $(r=0.4 ; p>0.05)$ and barley $(r=0.82 ; p<0.05)$ at $\mathrm{BBCH} 12$ stage, but at $\mathrm{BBCH}$ 31 stage it decreased. The electron transport rate increased in both wheat $(r=0.82 ; p<0.05)$ and barley $(r=0.58 ; p<0.05)$ at $\mathrm{BBCH} 12$ stage too. With increasing sapropel concentration chlorophyll $a+b$ content in wheat $(r=0.94)$ and barley $(r=0.81)$ increased significantly $(p<0.05)$, and the changes in the content of carotenoids in both plant species followed the same tendency $(r=0.87, p<0.05)$.

Keywords: wheat, barley, sapropel, fertilizer, photosynthesis, fluorescence

* Corresponding author. E-mail: irena.januskaitiene@vdu.lt 


\section{INTRODUCTION}

During last decades plant fertilization became the main tool in increasing yield mainly for such species as maize, rice, wheat or barley. However, the use of inorganic fertilizer has recently become more of a problem than a benefit, because often it is related to soil acidity lowering, nutrient misbalance and a lower yield quality (UN, 2011). The most concerning thing is the decline of organic matter in soil when inorganic fertilizers are used year after year without giving the organic matter amount a chance to restore. Meanwhile, the amount of organic matter is one of the most important components for plant growth. A strong correlation was found between the amount of soil organic matter and the amount of organic matter which is returned to soil when plants are decomposing (Trapani et al., 1999; Sokolov et al., 2008).

Sapropel is a sediment type rich in organic matter and other elements, which is naturally formed in ponds and lakes when water flora and fauna sink to the bottom and decompose. Sapropel accumulates in most of the world's freshwater lakes and ponds, and mainly its mass is accumulated in 5-6 to 10-12 m depth. Sapropel layer thickness can vary from 0.5 to 5-7 meters (Blečić et al., 2014). About 400 million tons of dry sapropel can be obtained from cleaning only Lithuanian lakes alone, and successfully used as an organic fertilizer in farming (Kavaliauskienè, 2000; Staugaitis ir kt., 2011). Its composition contains large amounts of nitrogen, phosphorus and potassium as well as such elements as $\mathrm{Co}, \mathrm{Mn}, \mathrm{Cu}, \mathrm{B}, \mathrm{Br}, \mathrm{Mo}$ and etc., 17 amino acids, vitamins, and enzymes (Agafonova et al. 2015). Sapropel composition can be up to $95 \%$ organic matter its mass. Its usefulness as a fertilizer has been proved many times (Ievina et al. 2014). While sapropel composition contains lots of macro and microelements necessary for plants growth, its wide positive effect surpasses synthetic-organic fertilizers. Sapropel mineralisation is slow so its positive effect on soil stays for several years (Kavaliauskienè, 2000; Bates, Lynch, 2000; Fillery, 2007). Also it is known to strongly boost such processes as photosynthe- sis, which is the main source of plant energy in whole biosphere (Lawlor, 2002). The main difference between sapropel and soil is that sapropel has assimilable nitrogen $(60-80 \%)$ and has three times less biochemically stable fractions. In addition, according to the existing mutual connection between biologic action of humic acids, these fractions, has more effective simulative impact on the photosynthesis of plants (Sviridova, Kosulnikova, 2007).

Lots of environmental problems are being created because of today's trends in fertilizer usage, and it is important to search for alternatives. Sapropel extraction could be a perfect and ecological solution to this problem with wide usage opportunities.

\section{MATERIALS AND METHODS}

Sapropel of Tarosiškis Lake was investigated in this experiment. The composition of sapropel was investigated at the wastewater laboratory of UAB Vilniaus vandenys. The content of nitrogen in dry sapropel varied from 54.8 to $78.2 \mathrm{~g}$ $\mathrm{N} / \mathrm{kg}$ sapropel.

Sapropel was prepared according to Booth et al. (2007), i. e., it was frozen at $-10^{\circ} \mathrm{C}$ for one week to break its primary structure and to ease its mineralisation.

According to nitrogen fertilisation limits for organic fertilizers (including sapropel), the concentration of nitrogen in the soils is $170 \mathrm{~kg} \mathrm{~N} / \mathrm{ha}$ (91/676/EEB), so in an area of one hectare 2.23.1 tons of dry sapropel can be added. Evaluating these facts, 2.2, 3.1 and $4 \mathrm{t}$ /ha dry sapropel concentrations were chosen in the growth substrate for investigation.

During the experiment, plants were grown in pots, 10 seeds per pot, with light loamy soil mixed with needed concentration of sapropel. The effect of sapropel on investigated plants was compared with two reference groups of plants grown in unfertilized soil and in soil with inorganic fertilizers. The norm of inorganic fertilizers NPK 14-14-14 was $400 \mathrm{~kg} / \mathrm{ha}$, so this amount was recalculated to the required growth area of the one-litre pot for fertilisation in this experiment. 
Plants were grown in growth chambers with controlled climate (photoperiod duration 14 hours) and watered regularly.

On day 14 of the experiment, when the plants unfolded two leaves (BBCH 12) (Growth stage, 2000), chlorophyll fluorescence parameters were measured. The plants were grown for another four weeks until the stem elongation stage $\mathrm{BBCH} 31$ (Growth stage, 2000), and then the content of pigments and chlorophyll fluorescence parameters were measured once again.

Concentrations of photosynthesis pigments were analysed in acetone extract using a spectrophotometer according to Wettstein (1957).

Chlorophyll fluorescence was determined using Hansatech company fluorimeter, Handy Pea. Measurements were performed by applying special clips to healthy leaves and darkening them for $15 \mathrm{~min}$. Then the measuring sensor was applied to the clipper and measurement was taken (Hansatech Instruments, 2006).

The measured parameters:

Fv/Fm - maximum II photosystem quantum efficiency rate.

PI - photosynthesis index
ETR - electron transport rate, calculated using the formula:

$\mathrm{ETR}=\mathrm{Fv} / \mathrm{Fm}^{\star} \mathrm{F}^{\star} \mathrm{PPFD}^{\star} \alpha$

where: ETR - the electron transport rate in quants per second ( $\mathrm{q} / \mathrm{s})$; Fv/Fm - maximum II photosystem quantum efficiency rate; $\mathrm{F}$ - the coefficient for C3 plants (0.5); PPFD - the fluorimeter photon light stream in quants (1800); $\alpha$ - leaf absorption.

All measurements were carried out in three replications.

The Pearson correlation coefficient, $r$, and the $p$-values were used for the assessment of sapropel concentration effect on the investigated plant parameters. Student's $t$ test was used for an independent comparison of variables. All analyses were performed by STATISTICA and EXEL, and the results were expressed as mean values and their standard error ${ }^{\star} 1.96\left(\mathrm{SE}^{\star} 1.96\right)$.

\section{RESULTS}

The increase of sapropel concentration in soil strongly stimulated the efficiency of the II photosystem $(\mathrm{Fv} / \mathrm{Fm})$ of both investigated plants at the BBCH 12 development stage (Fig. 1). It was found that by increasing the concentration of

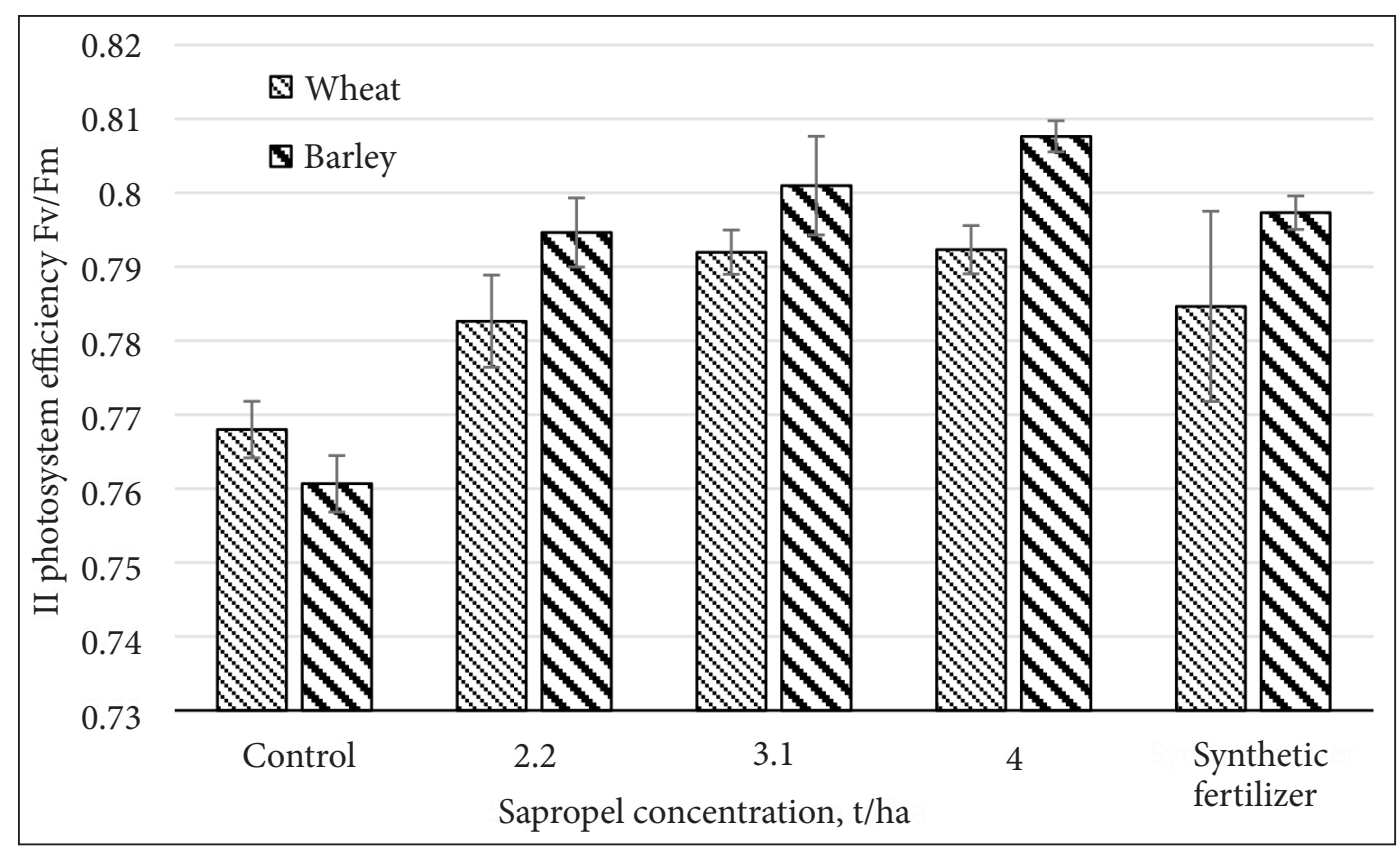

Fig. 1. Changes in wheat and barley II photosystem efficiency Fv/Fm at different sapropel concentrations $(\mathrm{t} / \mathrm{ha})$ at the $\mathrm{BBCH} 12$ development stage $\left(\mathrm{SE}^{\star} 1.96\right)$ 
sapropel in soil, the Fv/Fm ratio in wheat and barley leaves at the $\mathrm{BBCH} 12$ stage increased $(r=0.97 ; p<0.05$; and $r=0.98$; $p<0.05$, respectively) significantly (Fig. 1). The Fv/Fm value of both plants fertilized with $4 \mathrm{t} / \mathrm{ha}$ sapropel was higher than the value of the plants fertilized with a synthetic fertilizers $(p>0.05$ for wheat, $p<0.05$ for barley) and control plants (both $p<0.05$ ).
While after four weeks, at the stem elongation stage, the $\mathrm{Fv} / \mathrm{Fm}$ ratio of wheat increased too, but statistically insignificantly $(p>0.05)$ (Fig. 2). The II photosystem efficiency rate of barley plants began to fall $(r=-0.91 ; p>0.05)$ by increasing sapropel concentration.

The measurements of the photosynthesis index - PI (Fig. 3) - showed that, with increasing of

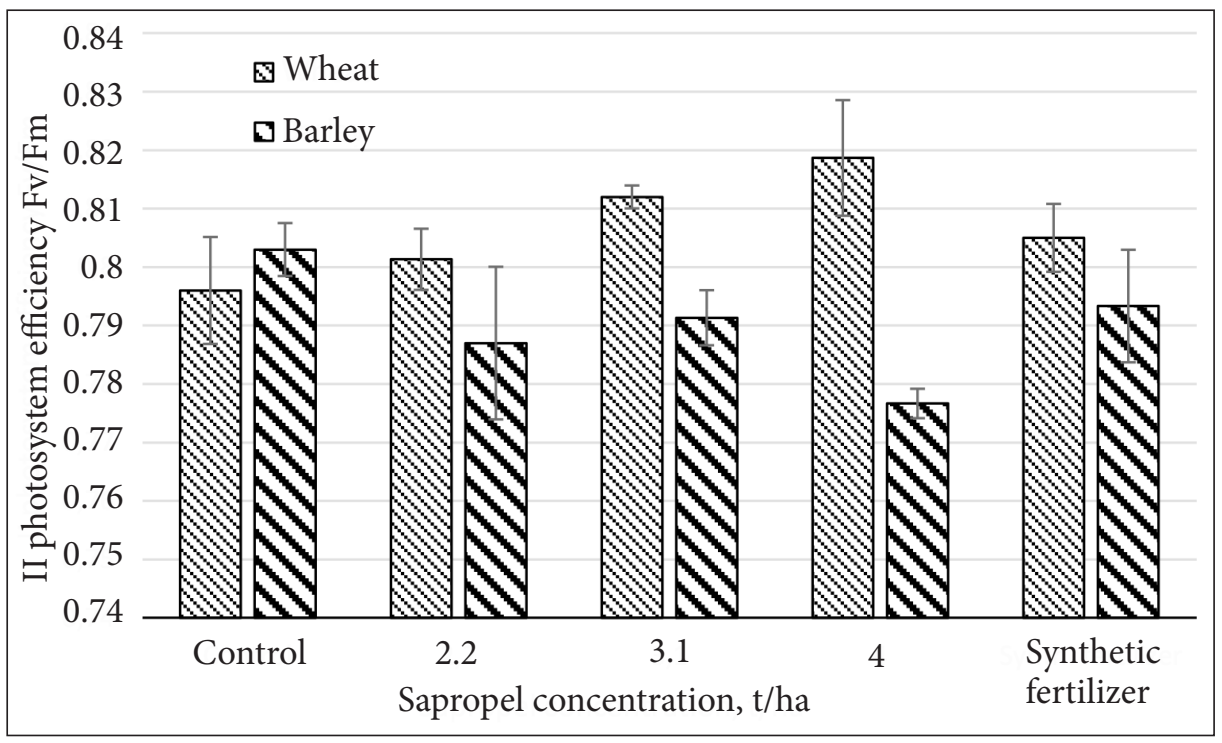

Fig. 2. Changes in wheat and barley II photosystem efficiency Fv/Fm at different sapropel concentrations ( $\mathrm{t} / \mathrm{ha}$ ) at the $\mathrm{BBCH} 31$ development stage $\left(\mathrm{SE}^{\star} 1.96\right)$

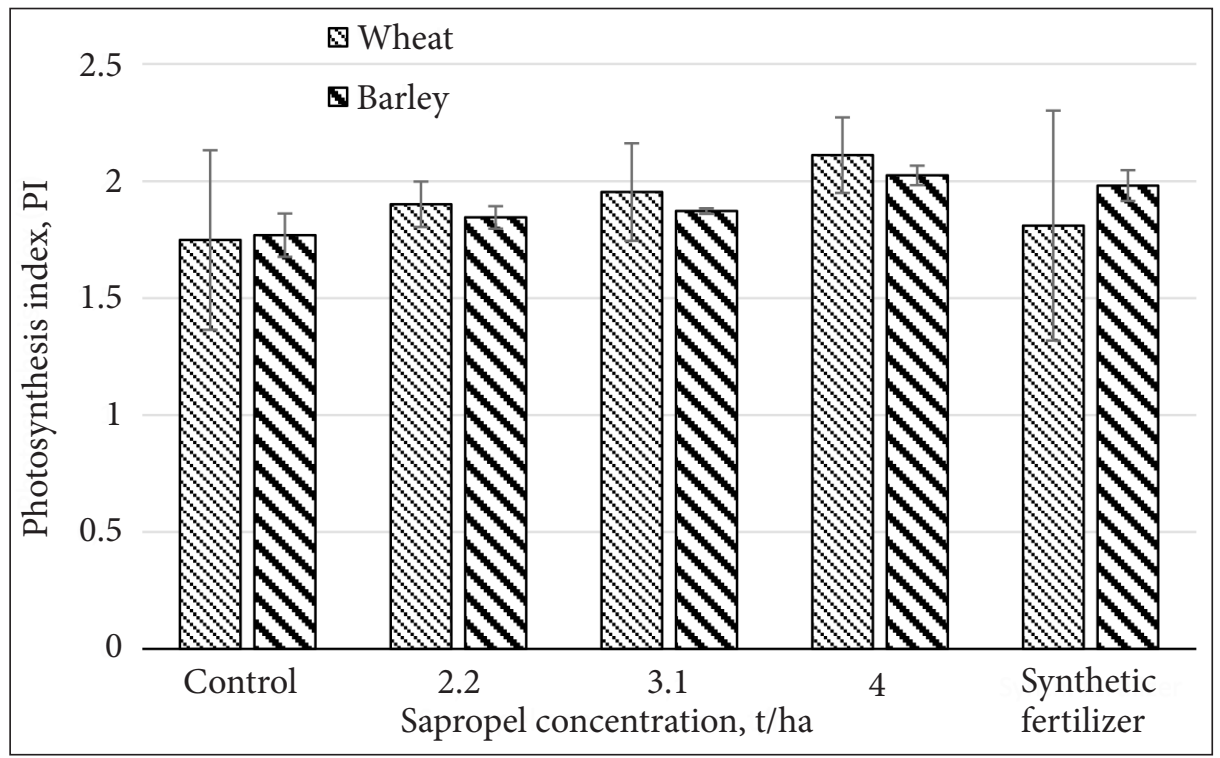

Fig. 3. Changes in wheat and barley photosynthesis index PI at different sapropel concentrations $(\mathrm{t} / \mathrm{ha})$ at the $\mathrm{BBCH} 12$ development stage (SE*1.96) 
sapropel concentration in soil, the PI of wheat increased $(r=0.4 ; p>0.05)$. The largest photosynthesis index was detected in the wheat fertilized with $4 \mathrm{t} /$ ha sapropel concentration when it was $17 \%$ higher than in control plants $(p>0.05)$, and $14 \%$ higher than in the plants fertilized with a synthetic fertilizer $(p>0.05)$. The PI index of barley increased $r=0.82(p<0.05)$ along with increasing sapropel concentration (Fig. 3). The largest PI was recorded for the barley fertilized with $4 \mathrm{t} / \mathrm{ha}$ sapropel, but and it differed a little from the barley fertilized with a synthetic fertilizer.

When plants reached the stem elongation stage, completely opposite changes of the PI (Fig. 4) were detected, i. e., by increasing the sapropel concentration, the PI of wheat decreased $(r=-0.4 ; p>0.05)$, and the largest PI was measured in plants affected by the synthetic fertilizer when the PI was $44 \%(p<0.05)$ higher than in $4 \mathrm{t} /$ ha sapropel-affected plants and $21 \%$ $(p<0.05)$ higher than in the control plants. At the stem elongation stage the PI of barley began to fall $r=-0.73$ significantly $(p<0.05)$. Compared to the control plants, the photosynthesis index of $4 \mathrm{t} / \mathrm{ha}$-affected plants was $37.4 \%$ $(p>0.05)$ lower, and compared to the plants fer- tilized with a synthetic fertilizer $29 \%(p>0.05)$ lower.

The electron transport rate (ETR) of wheat at the leave development stage increased significantly but inconsistently $(r=0.82 ; p<0.05)$ (Fig. 5). The highest ETR value was detected in $4 \mathrm{t} / \mathrm{ha}$ sapropel concentration affected plants when it was $2-3 \%$ higher than in the plants fertilized with a synthetic fertilizer $(p<0.05)$ or control plants $(p<0.05)$. The ETR of barley at the BBCH 12 development stage with increasing sapropel concentration also increased $(r=0.58 ; p<0.05)$. When both investigated plants reached the stem elongation stage, an increase in the sapropel concentration reduced the electron transport rate $r=-0.31(p>0.05$ both plants) (Fig. 6).

At the end of the experiment, i. e., at the stem elongation stage of investigated plants the content of photosynthetic pigments was determined (Fig. 7, 8). The strongest correlation $r=0.94$ between chlorophyll $a+b$ concentrations in leaves and the sapropel concentration in soil was found for wheat $(p<0.05)$. In the wheat fertilized with $4 \mathrm{t} / \mathrm{ha}$ sapropel the chlorophyll $a+b$ content was $2 \%(p>0.05)$ higher than in the wheat fertilized with a synthetic fertilizer. Meanwhile, in barley

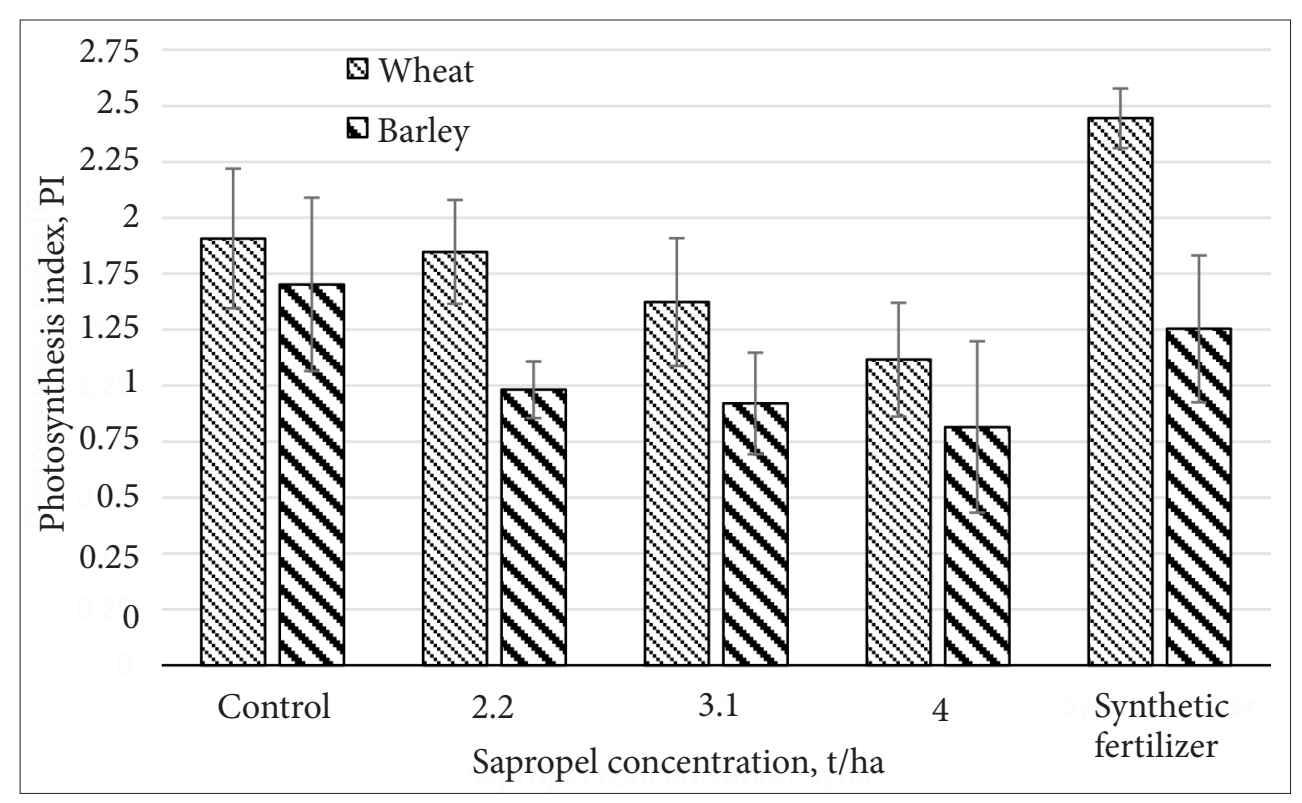

Fig. 4. Changes in wheat and barley photosynthesis index PI at different sapropel concentrations $(\mathrm{t} / \mathrm{ha})$ at the $\mathrm{BBCH} 31$ development stage $\left(\mathrm{SE}^{\star} 1.96\right)$ 


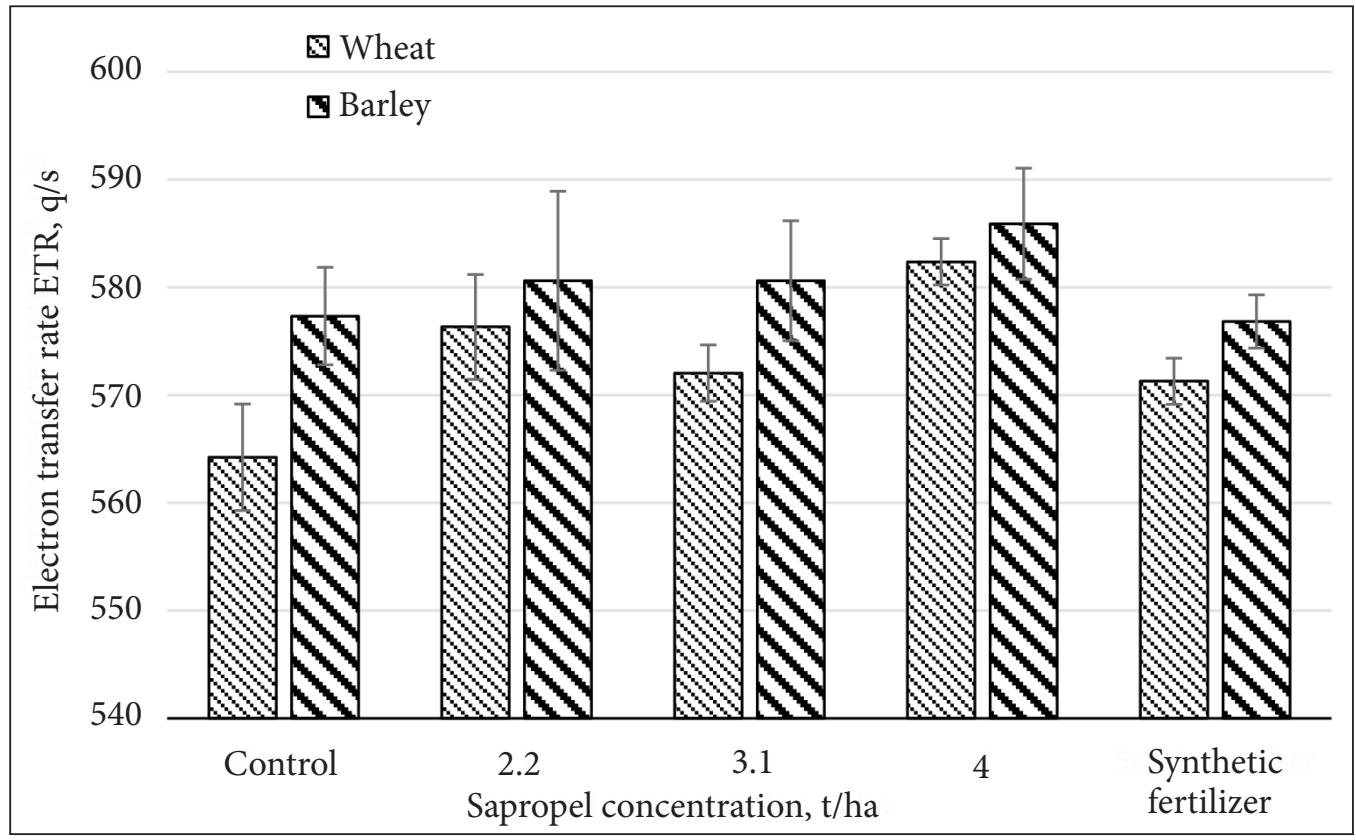

Fig. 5. Changes in wheat and barley electron transport rate (ETR) at different sapropel concentrations ( $\mathrm{t} / \mathrm{ha})$ at $\mathrm{BBCH} 12$ plant development stage $\left(\mathrm{SE}^{\star} 1.96\right)$

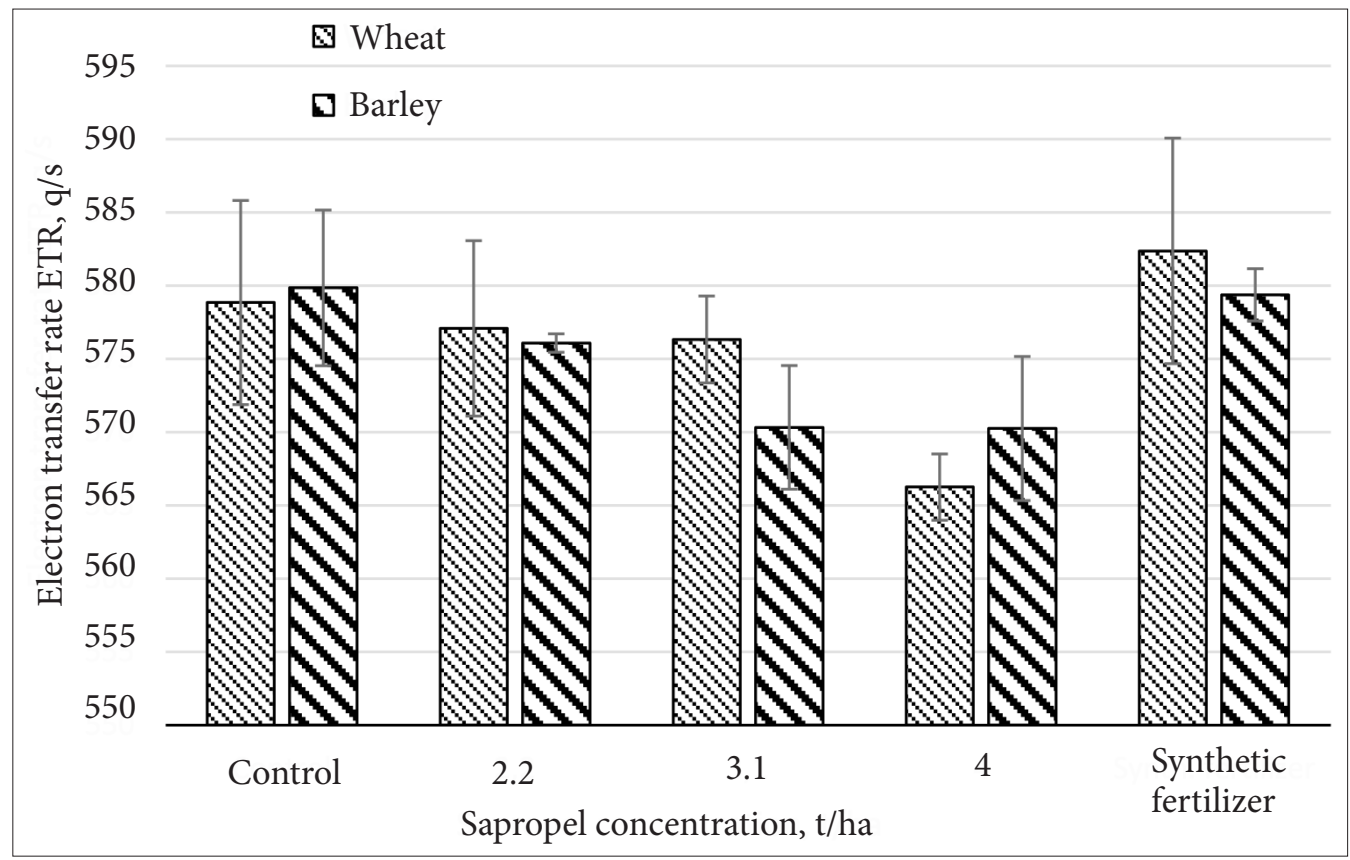

Fig. 6. Changes in wheat and barley electron transport rate (ETR) at different sapropel concentrations ( $\mathrm{t} / \mathrm{ha})$ at $\mathrm{BBCH} 31$ plant development stage $\left(\mathrm{SE}^{\star} 1.96\right)$

the correlation between chlorophyll $a+b$ and the sapropel concentration in soil was not as strong as in wheat $(r=0.81, p<0.05)$.
The changes in the content of carotenoids were very similar to those in the content of chlorophylls $a+b$ (Fig. 5). With increasing sapropel 


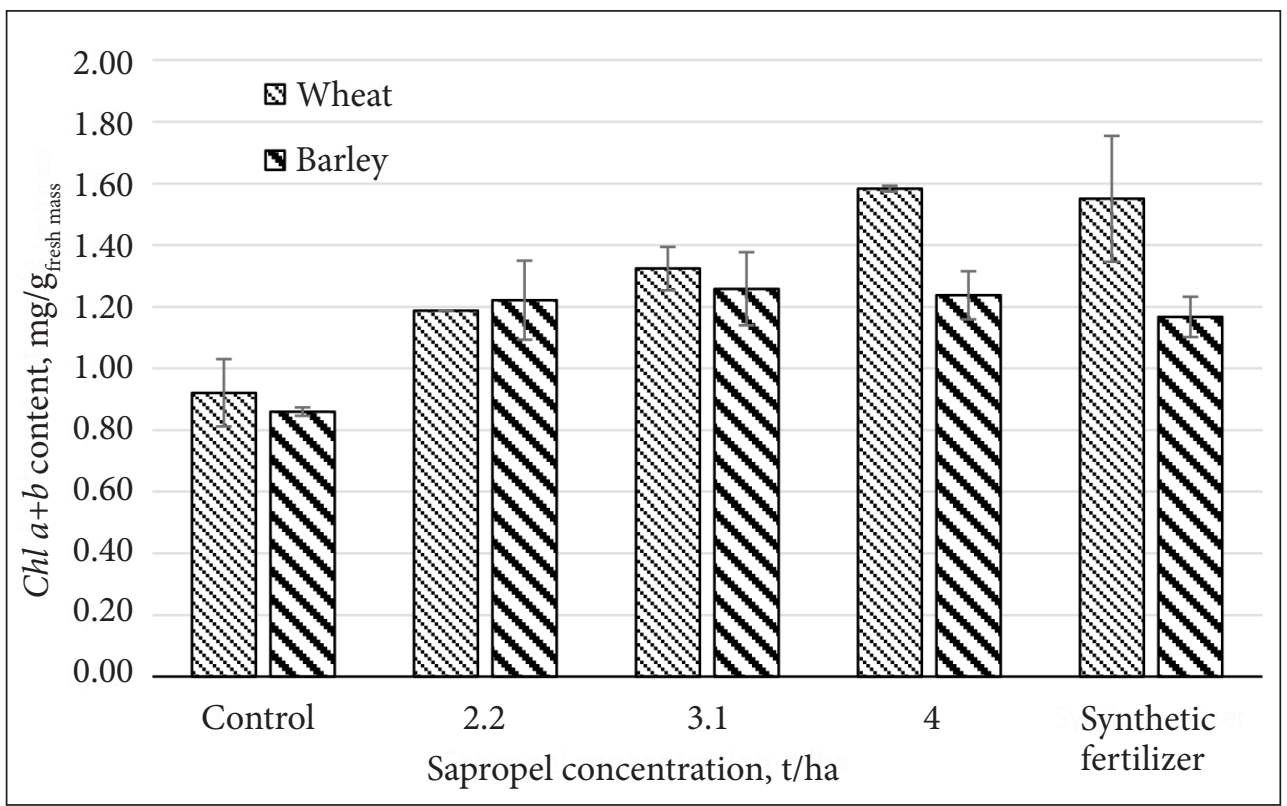

Fig. 7. Changes in wheat and barley chlorophylls $a+b$ content at different sapropel concentrations ( $\mathrm{t} / \mathrm{ha}$ ) at $\mathrm{BBCH} 31$ plant development stage $\left(\mathrm{SE}^{\star} 1.96\right)$

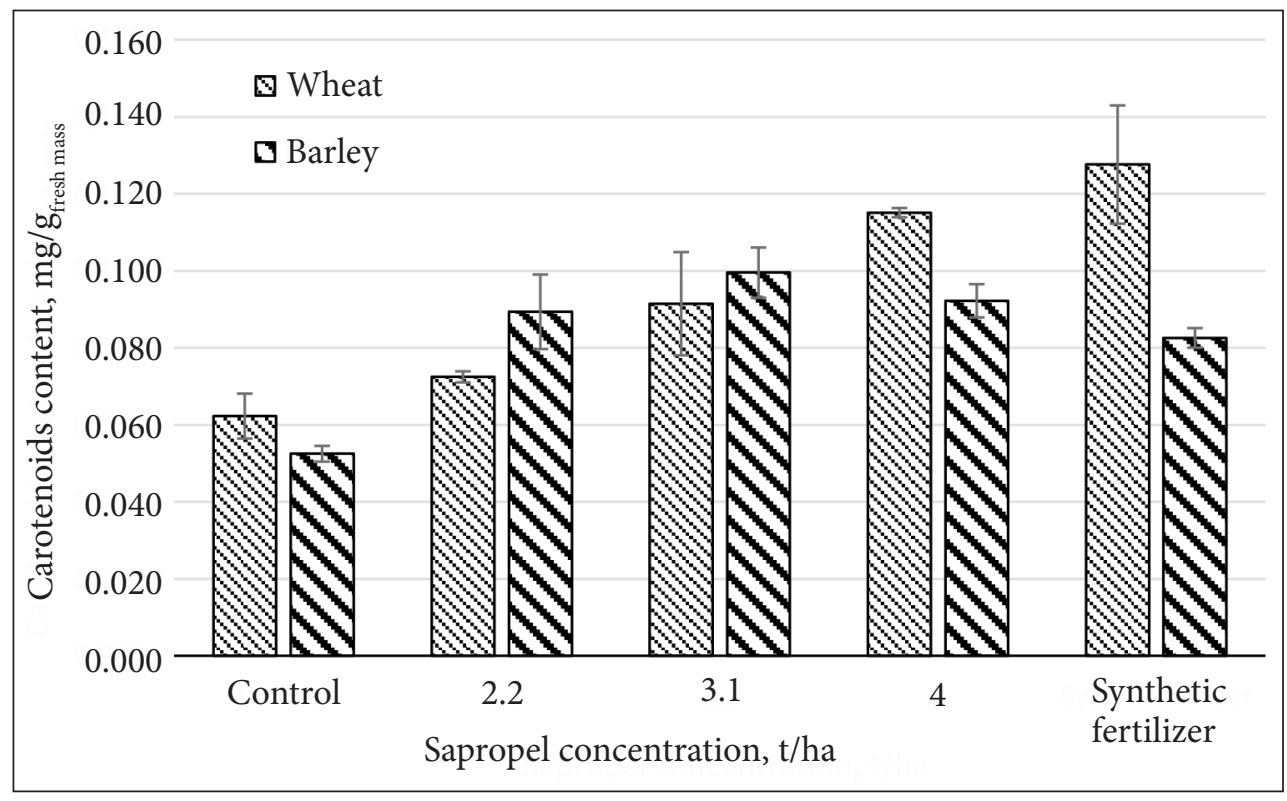

Fig. 8. Changes in wheat and barley carotenoids content at different sapropel concentrations ( $\mathrm{t} / \mathrm{ha})$ at $\mathrm{BBCH} 31$ plant development stage $\left(\mathrm{SE}^{\star} 1.96\right)$

concentration in soil, the content of carotenoids also increased in wheat leaves $(r=0.87, p<0.05)$. The highest concentration of carotenoids was found in the wheat fertilized with a synthetic fertilizer $-10.8 \%$ more than at the highest sapropel concentration. With increasing sapropel concentration in soil, the content of carotenoids in barley also increased $(r=0.87, p<0.05)$. At $3.1 \mathrm{t} /$ ha sapropel concentration, the content of carotenoids in wheat leaves increased by $89.6 \%$ more than in control plants, and at $4 \mathrm{t} / \mathrm{ha}$ sapropel concentration the effect was $75.7 \%$. 


\section{DISCUSSION}

It is known that sapropel can contain large amounts of nitrogen, phosphorus, manganese, iron, copper, or zinc. All these elements are essential for plant growth and, mainly, for photosynthesis (Broadley et al., 2007). Cechin and Fumis (2004) research showed that nitrogen deficiency leads to a significantly lower leaf weight. When sapropel enriches soil with nitrogen, the content of nitrogen in plant leaves also increases (Evans, 1989). The same applies to phosphorus, but it is stored in roots and can be transferred to parts of plants it is needed most by demand. (Li et al., 2001; Yong-fu et al., 2006). When a plant is low in zinc or any other microelement its photosynthesis rates fall. Zinc deficiency leads to a carbon-anhydrase (enzyme in $\mathrm{CO}_{2}$ fixation) activity disruption. Zinc is also used in signal transfer through protein kinases (Ciftci-Yilmaz, Mittler, 2008; Hansch, Mendel, 2009). Thus fertilization with sapropel not only helps to remove deficiency of macro and micro elements for plants, but also helps to take care of the soil quality.

As for separate photosynthesis parameters, $\mathrm{Fv} / \mathrm{Fm}$ is widely used to indicate the maximum quantum efficiency of photosystem II. This parameter is widely considered to be a sensitive indication of plant photosynthetic performance with healthy samples typically achieving a maximum $\mathrm{Fv} / \mathrm{Fm}$ value of approx. 0.85. Values lower than this will be observed if a sample has been exposed to some type of biotic or abiotic stress factor, which has reduced the capacity for photochemical quenching of energy within PSII (Hansatech Instruments, 2006). It is known that $\mathrm{Fv} / \mathrm{Fm}$ is relatively insensitive to such stress factors as drought, which can affect photosynthesis (Živčak et al., 2014). But Janušauskaite and Feizienè (2012) found that using the Fv/Fm ratio nitrogen deficiency can be noticed. Our findings also show a significant $(p<0.05)$ correlation between nitrogen-rich sapropel concentration and wheat $(r=0.97)$ and barley $(r=0.97) \mathrm{Fv} / \mathrm{Fm}$ ratio. Also it is important to notice that these changes can be due to many other elements, that sapropel consist.
The photosynthesis index (PI) is a good photosynthetic tissue vitality indicator. Živčák et al. (2014) found that the tin wheat PI correlates really well with nitrogen amount in the plant itself. They could not confirm that on the Fv/Fm ratio usage. The PI is closely related to the number of photosynthesis reaction centres. When a plant is getting low on nitrogen the number of reaction centres also decreases and the PI reacts to that. Similar results were found in investigating soy and maize (Heerden et al., 2004). Also, it was noticed that the PI correlates well not only low nitrogen amounts, but also with low chlorophyll levels and low biomass growth. Since nitrogen deficiency lowers photosynthesis efficiency (Fv/ $\mathrm{Fm}$ ), it also lowers electron transport rates (ETR) in rice ( $\mathrm{Li}$ et al., 2012). The electron transport (ETR) can be closely related to nitrogen amount in plants. But it is important to notice that nitrogen determines not only electron transport, but lots of other elements and nutrients (Lambrev et al., 2012). In this research the same tendencies were detected. When the concentrations of nutrients in the soil decreased at the end of the experiment, all investigated parameters decreased too (Fig. 2, 4, 6).

Chlorophyll is especially sensitive to the changes of the nitrogen amount in soil (Kopsell et al., 2004). Fertilizing with nitrogen encourages the performance of the photosynthetic apparatus, helps to keep the chlorophyll $a$ and $b$ ratio stable, enhances growth, and slows development (Tranavičienè et al., 2007). Juchnevičienè et al. (2015) discovered that additional fertilising with nitrogen in late wheat development stages slows photosynthesis pigment degradation and prolongs their active photosynthesis period. In this way, adding nutrient and especially nitrogen-rich sapropel can improve most of photosynthesis chlorophyll content and fluorescence parameters in both wheat and barley at early stages of development.

\section{CONCLUSIONS}

Increasing sapropel concentration stimulated both barley and wheat photosynthesis parameters at the early stage of development. 
The strongest sapropel effect was detected on barley Fv/Fm parameter at the leave development stage $(r=0.98 ; p<0.05)$, while the effect on wheat was weaker $(r=0.97 ; \mathrm{p}<0.05)$.

The photosynthesis index also increased in both wheat $(r=0.4 ; p>0.05)$ and barley $(r=0.82 ; p<0.05)$ but only at the early stage of development (BBCH 12). Later, at the stem elongation stage sapropel effect on the PI of plants was opposite.

At the $\mathrm{BBCH} 12$ stage, the electron transport rate grew by increasing sapropel concentration in soil for both plants, and a stronger correlation was detected for wheat $(r=0.82 ; p<0.05)$ than for barley $(r=0.58 ; p<0.05)$.

The strongest correlation $r=0.94$ between chlorophyll $a+b$ content and sapropel concentration was found in wheat leaves $(p<0.05)$. Meanwhile, in barley the correlation between chlorophyll $a+b$ and sapropel concentration in soil was weaker $(r=0.81, p<0.05)$. Changes in the content of carotenoids followed the same tendency as chlorophylls $a+b$.

In most cases, $4 \mathrm{t} /$ ha sapropel concentration effect on barley and wheat photosynthesis parameters was greater than that of synthetic fertilizers.

(The paper was presented at the 10th International Scientific Conference 'The Vital Nature Sign 2016')

Received 31 August 2016 Accepted 22 November 2016

\section{References}

1. Agafonova L, Alsina, Sokolov G, Kovrik S, Bambalov, Apse J, Rak M. New kinds of sapropel and peat based fertilizers. Environment. Technology. Resource. 2015; II: 20-6.

2. Bates TR, Lynch JP. Plant growth and phosphorus accumulation of wild type and two root hair mutants of Arabidopsis thaliana Brassicaceae). Am J Bot. 2000. 87: 958-63.

3. Blečic A, Railić B, Dubljević R, Mitrović D, Spalevic V. Application of sapropel in agricultural production. Agriculture and Forestry. 2014; 243-50.

4. Booth CA, Baksiene E, Fullen MA, Ciūnys A. Long-term agrochemical dynamics: engineering, application and challenges of calcareous sapropel as a soil fertilizer. International Journal of Ecodynamics. 2007; 2(2): 108-16.

5. Broadley MR, White PJ, Hammond JP, Zelko I, Lux A. Zinc in plants. New Phytologist. 2007; 173(4): 677-702.

6. Cechin I, Fumis TF. Effect of nitrogen supply on growth and photosynthesis of sunflower plants grown in the greenhouse. Plant Science. 2004; 166: 1379-85.

7. Ciftci-Yilmaz S, Mittler R. The zinc finger network of plants. Cell. Mol. Life Sci. 2008; 65(7-8): 1150-60.

8. European Council Directive (91/676/EEB): Water sources protection from farming source nitrates. 1991 Dec 12.

9. Evans JR. Photosynthesis and nitrogen relationship in leaves of C3 plants. Oecologia. 1989; 78: 9-19.

10. Fillery IRP. Plant-based manipulation of nitrification in soil: a new approach to managing $\mathrm{N}$ loss? Plant and Soil. 200; 7(294): 1-4.

11. Growth stages of mono- and dicotyledonous plants. In: Meier U, editor, BBCH monograph. German Federal Biological Research Centre for Agriculture and Forestry 2001. 14-8.

12. Hansatech Instruments. Handy Handy PEA, Pocket PEA \& PEA Plus Software Operations Manual. Version 1.0 England, 2006.

13. Hansch R, Mendel RR. Physiological functions of mineral micronutrients $(\mathrm{Cu}, \mathrm{Zn}, \mathrm{Mn}$, $\mathrm{Fe}, \mathrm{Ni}, \mathrm{Mo}, \mathrm{B}, \mathrm{Cl}$ ) Current Opinion in Plant Biology. 2009; 12: 259-66. 
14. Heerden PD, Strasser RJ, Krüger GH. Reduction of dark chilling stress in N2-fixing soybean by nitrate as indicated by chlorophyll a fluorescence kinetics. Physiologia Plantarum. 2004; 121: 239-49.

15. Ievina GL, Karlsons A, Ozola UA. Effect of freshwater sapropel on plants in respect to its growth - affectingactivity and cultivable microorganism content. ŽemdirbystèAgriculture. 2014; 101(4): 355-66.

16. Janušauskaitė D, Feizienè D. Chlorophyll fluorescence characteristics throughout spring triticale development stages as affected by fertilization. Soil and Plant Science. 2012; 62(1): 7-15.

17. Juchnevičienė A, Vagusevičienè I, Kaminskaitė A, Brazaitytė A, Duchovskis P. Azoto trąšu poveikis skirtingų žieminių kviečių veislių fotosintetiniams rodikliams. Žemès ūkio mokslai. 2015; 22(1): 15-25.

18. Kavaliauskienè J. Species composition of phytoplankton in some Lithuanian karst lake. The Geographical Yearbookю 2000; 34: 233-9.

19. Kopsell DA, Kopsell DE, Lefsrud MG, CurranCelentano J, Dukach LE. Variation in lutein, $\beta$-carotene and chlorophyll concentrations among Brassica oleracea cultigens and seasons. Hortscience. 2004; 39(2): 361-4.

20. Lambrev PH, Miloslavina Y, Jahns P, Holzwarth AR. On the relationship between non-photochemical quenching and photoprotection of Photosystem II. Biochimica et Biophysica Acta. 2012; 1817: 760-9.

21. Lawlor DW. Carbon and nitrogen assimilation in relation to yield: mechanisms are the key to understanding production systems, J. Exp. Botany. 2002; 53: 773-87.

22. Li G, Zhang ZS, Gao HY, Liu P, Dong ST, Zhang JW, Zhao B. Effects of nitrogen on photosynthetic characteristics of leaves from two different stay-green corn (Zea mays L.) varieties at the grain-filling stage. Canadian Journal of Plant Sciences. 2012; 92: 671-80.

23. Li HB, Xia M, Wu P. Effect of phosphorus deficiency stress on rice lateral root growth and nutrient absorption. Acta BotSin. 2001; 43: 1154-60.

24. Sokolov G, Szajdak L, Simakina I. Changes in the structure of nitrogen-containing compounds of peat-, sapropel-, and brown coalbased organic fertilizers. Agronomy Research. 2008; 6(1): 149-60.

25. Staugaitis G, Mažeika R, Antanaitis A, Antanaitis Š. Komposto, naudojamo žemès ūkyje, kokybės reikalavimų analizė ir ịvertinimas. Kaunas: Lietuvos agrarinių ir miškų mokslo centro agrocheminių tyrimų laboratorija, 2011.

26. Sviridova LL, Kosulnikova TL. Elements of photosynthetic productivity of potato depending on fertilizer and moisture. Vestnik Belorusskoi gosudarstvennoi selskokhoziaistvennoi akademii. Bulletin of the Belarus State Agricultural Academy. 2007.

27. Tranavičienė $\mathrm{T}$, Šikšnianienė JB, Urbonavičiūtė A, Vagusevičienė I, Samuolienė G, Duchovskis P, Sliesaravičius A. The effect of nitrogen fertilizers on wheat photosynthetic pigment and carbohydrate contents. Biologija. 2007; 53(4): 84-8.

28. Trapani N, Hall AJ, Weber M. Effects of constant and variable nitrogen supply on sunflower (Helianthus annuus L.) leaf cell number and size, Ann. Botany. 1999; 84: 599-606.

29. United Nations Food and Agriculture Organization. 2011. Current world fertilizer trends and outlook to 2015. Rome. p. 43.

30. Wettestein D. Chlorophyll Letale und der submikroskopische Formwechsel der Plastiden. Exp. Cell. Res. 1957; 12: 427.

31. Yong-fu L, An-cheng L, Hassan MJ, Xinghua W. Effect of Phosphorus Deficiency on Leaf Photosynthesis and Carbohydrates Partitioning in Two Rice Genotypes with Contrasting Low Phosphorus Susceptibility. Rice Science. 2006; 13(4): 283-90.

32. Živčák M, Olšovsk K, Slamka P, GalambošováJ, Rataj V, Shao H-B, Kalaji HM, Brestič M. Azoto trūkumo nustatymas kviečiuose matuojant skirtingose pozicijose esančių lapu fluorescenciją. Žemdirbystè-Agriculture. 2014; 101(4): 437-44. 
Martynas Klepeckas, Irena Januškaitienè

TRITICUM AESTIVUM IR HORDEUM VULGARE CHLOROFILŲ KIEKIO IR FLUORESCENCIJOS RODIKLIŲ POKYČIAI NAUDOJANT SKIRTINGĄ SAPROPELIO KONCENTRACIJĄ

\section{Santrauka}

Šio tyrimo tikslas yra ištirti Tarosiškio ežero sapropelio poveikị kviečių (Triticum aestivum L.) ir miežių (Hordeum vulgare L.) fotosintezès rodikliams (chlorofilų kiekiui ir chlorofilų fluorescencijai). Tam tikslui augalai buvo paseti i 11 talpos vegetacinius indus po 10 sèklų ir auginami fitokamerose. Atsižvelgiant i sapropelio sudetit, tyrimams pasirinktos 2,2; 3,1 ir 4 t/ha sauso sapropelio koncentracijos. Sapropelio poveikis lygintas su augalais, augintais be trąšų ir tręštais sintetinėmis trąšomis. Keturioliktą eksperimento dieną, kai augalai išleido du lapus (BBCH 12), buvo išmatuoti chlorofilų fluo- rescencijos rodikliai. Augalus paauginus dar 4 savaites (stiebų ilgejjimo etapas BBCH 31), pakartotinai buvo išmatuoti chlorofilų fluorescencijos rodikliai ir nustatyti chlorofilų bei karotinoidų kiekiai lapuose. Esant BBCH 12 išsivystymo etapui, didesnè sapropelio koncentracija dirvožemyje lèmė statistiškai reikšmingą kviečių Fv / Fm santykio didejimą $(r=0,97 ; p<0,05)$, tačiau stiebų ilgejjimo etape šis didejimas nebuvo reikšmingas $(r=0,97 ; p>0,05)$. Miežių Fv / Fm santykio pokyčiai buvo tokie patys. Didejant sapropelio koncentracijai, tiek kviečiuc $(r=0,4 ; p>0,05)$, tiek miežių $(r=0,82 ; p<0,05)$ PI indeksas didèjo, tačiau jis sumažèjo pasiekus $\mathrm{BBCH} 31$ etapą. Elektronų pernaša taip pat buvo greitesnè tiek kviečiuose $(r=0,82 ; p<0,05)$, tiek miežiuose $(r=0,58 ; p<0,05)$ esant $\mathrm{BBCH} 12$ išsivystymo etapui. Chlorofilų $a+b$ kiekis kviečių $(r=0,94)$ ir miežių $(r=0,81)$ lapuose didejo reikšmingai $(p<0,05)$ didejant sapropelio kiekiui. Karotinoidų kiekio pokyčiai buvo tokie patys $(r=0,87 ; p<0,05)$.

Raktažodžiai: kviečiai, miežiai, sapropelis, trąšos, fotosintezè, fluorescencija 